\title{
Molecular Typing of Clostridium perfringens Isolates from Faecal Samples of Healthy and Diarrhoeic Sheep and Goats in Kashmir, India
}

\author{
S. Rasool ${ }^{1}$, I. Hussain ${ }^{1}$, S.A. Wani ${ }^{1}$, Z.A. Kashoo ${ }^{1}$, Q. Beigh ${ }^{1}$, Q. Nyrah ${ }^{1}$, \\ N. Nazir ${ }^{1}$, T. Hussain ${ }^{2}$, A.H. Wani ${ }^{1}$ and S. Qureshi ${ }^{1}$ \\ ${ }^{1}$ Bacteriology Laboratory, Division of Veterinary Microbiology and Immunology, Sher-e- \\ Kashmir University of Agricultural Sciences and Technology of Kashmir, \\ Shuhama (Alusteng), Srinagar 190006, India \\ ${ }^{2}$ Division of Veterinary Clinical Medicine, Sher-e-Kashmir University of Agricultural Sciences \\ and Technology of Kashmir, Shuhama (Alusteng), Srinagar 190006, India \\ *Corresponding author
}

A B S T R A C T

The current study reports the occurrence and molecular toxinotyping of Clostridium perfringens (C. perfringens) isolated from sheep and goat in Kashmir valley. A total of 462 faecal samples were collected from different organized and unorganized sheep and goat farms of the Kashmir valley. The samples consisted of 223 samples from sheep (adult-138, lamb-46) and goats (adult-15, kid-24) without diarrhoea (healthy) and 239

Keywords

Clostridium perfringens, Sheep, Goat, Toxinotype, Multiplex PCR.

Article Info

Accepted:

26 September 2017

Available Online:

10 October 2017 samples from sheep (adult-71, lamb-121) and goats (adult-17, kid-13) with diarrhoea. $C$. pefringens was isolated from 286 samples using Robertson's cooked meat media and Sulphite Polymixin Sulphadiazine (SPS) agar. The isolates were confirmed by 16S rRNA specific PCR. Out of the 138 adult sheep and 46 lamb samples without diarrhoea, $C$. perfringens was obtained from 63(45.6\%) and 27(58.6\%) samples, respectively. Similarly, $51(71.8 \%)$ and $91(76 \%)$ samples from 71 adult sheep and 121 lambs with diarrhoea, respectively yielded $C$. perfringens. Likewise, $8(53.3 \%)$ and $16(66.6 \%)$ isolates were recovered from 15 and 24 healthy adult goat and kid samples, respectively. The diarrhoeic samples yielded $17(58.6 \%)$ and $13(72.2 \%)$ isolates from adult goats and kids, respectively. Among the 286 isolates from 462 samples, 228(79.72\%) were typed as toxinotype A, $197(86.4 \%)$ of which had only cpa gene and 31(13.6\%) carried both cpa and cpe gene. Other 58(20.2\%) isolates harboured both cpa and etx genes and thus were designated as toxinotype D. Majority of the type D isolates $(58.6 \%)$ were from diarrhoeic lamb and this is followed by healthy lamb (15.5\%), diarrhoeic adult sheep (8.6\%) and others $(3.5-5.2 \%)$. None of the isolates belonged to $C$. perfringens type B, C or E as they were negative for $c p b$ or cpi genes.

\section{Introduction}

The Gram-positive bacterium Clostridium perfringens ( $C$. perfringens) is an important human and veterinary pathogen, and it is most appreciated for its tremendous toxinproducing capability (Rood, 1998).
C. perfringens is believed to be the most wide-spread bacterial pathogen in nature (Quinn et al., 2002), as it can be found in water, soil sediments, and also part of the normal intestinal flora of humans and 
animals. As a member of the genus Clostridium, C. perfringens is, Gram-positive, anaerobic spore forming bacterium and able to produce various toxins and enzymes responsible for the associated lesions and symptoms (Varga et al., 2006).Clostridium perfringens causes enterotoxaemia, which are acute, highly fatal intoxications that affect sheep, goats, lambs, calves, piglets and occasionally foals as well (Markey et al., 2013).

C. perfringens strains are classified into five toxinotypes, $\mathrm{A}$ to $\mathrm{E}$ according to the production of four major extracellular toxins namely alpha $(\alpha)$, beta $(\beta)$, epsilon $(\varepsilon)$ and iota $(1)$, while various strains can also produce other toxins including $\beta 2$, theta $(\theta)$ (perfringolysin $\mathrm{O}$ ), kappa $(\kappa)$, delta $(\delta)$, $\operatorname{mu}(\mu)$, enterotoxin, necrotic enteritis B-like toxin (NetB), TpeL (toxin $C$. perfringens large cytotoxin) etc. Type A produces $\alpha$ toxin, type $\mathrm{B}$ produces $\alpha, \beta$ and $\varepsilon$ toxins, type $\mathrm{C}$ produces $\alpha$ and $\beta$ toxins, type D produces $\alpha$ and $\varepsilon$ toxins and type $\mathrm{E}$ produces $\alpha$ and 1 toxins ( $\mathrm{Li}$ et al., 2013). The epsilon toxin (ETX)produced by both $C$. perfringens type B and $\mathrm{D}$ strains ranks as the third most potent clostridial toxin after the botulinum and tetanus toxin (Chen et al., 2011). $C$. perfringens type D mainly affects sheep and goats and more rarely cattle and other animal species (Songer, 1996; Songer, 1997). The ETX produced by $C$. perfringens type D plays a major role in fatal enterotoxaemia or pulpy kidney disease in sheep and other small ruminants (Souza et al., 2010). C. perfringens type $\mathrm{B}$, which also produces $\beta$-toxin, is the etiological agent of dysentery in newborn lambs, but is also associated with enteritis and enterotoxaemia in calves, goats and foals (Songer, 1996; Songer, 1997). These isolates may be found in the intestine of normal animals, including sheep, goats, and cattle (Uzal and Songer, 2008). However, when the microbial balance of the gastrointestinal flora is disrupted, these bacteria proliferate in large numbers and produce disease, which is thought mainly to be mediated by toxins. Goats and lambs fed on high fiber diets are considered at a higher risk of epsilon toxin induced enterotoxemia (Smedley et al., 2004).

Various PCR protocols including multiplexPCR have been developed to detect the toxin genes to type $C$. perfirngens isolates (Ahsani et al., 2010).Compared to conventional methods, these protocols provide rapid and sensitive detection of the organisms. The multiplex PCR method may provide a more sophisticated approach, enabling a simultaneous and specific detection of all the toxinotypes of $C$. perfringens. Many studies have been carried out for the detection of $C$. perfringens toxin genotypes by multiplex PCR using primers specific for each of the toxin genes present (Elsify et al., 2016). Typing of toxin gene by PCR has advantage of being practicable directly from primary culture colonies and hence is able to detect toxin genes, which are unstably maintained and might be lost during the cultivation process otherwise needed for the biological method (Kadra et al., 1999). The present study was undertaken to isolate and identify $C$. perfringens from sheep and goats and to characterize them into different toxinotypes as there is no information available on $C$. perfringens of sheep and goats origin in the Kashmir valley.

\section{Materials and Methods}

\section{Sampling}

A total of 462 faecal samples were collected from different organized and unorganized sheep and goat farms of the Kashmir valley. The samples were comprised of 223 samples from sheep (adult-138, lamb-46) and goats (adult-15, kid-24) without diarrhoea (healthy) and 239 samples from sheep (adult-71, lamb- 
121) and goats (adult-29, kid-18) with diarrhoea. The samples were collected with sterile swabs and carried on ice to the laboratory, where they were processed immediately for isolation of $C$. perfringens.

\section{Isolation and identification of Clostridium perfringens}

For isolation of $C$. perfringens, samples were inoculated in Difco ${ }^{\mathrm{TM}}$ Cooked meat medium (Becton, Dickinson and Company, Sparks, MD, USA) and incubated anaerobically in 3.5 litre anaerobic jar (Oxoid Limited, Thermo Fisher Scientific Inc., UK) with $\mathrm{GasPak}^{\mathrm{TM}}$ Anaerobe Container System (Becton, Dickinson and Company, Sparks, MD, USA) at $37^{\circ} \mathrm{C}$ for $24 \mathrm{hrs}$. Enriched samples were streaked on Sulphite Polymixin Sulphadiazine agar plates (SPS HiVeg ${ }^{\mathrm{TM}}$ Agar, Modified; Hi-Media laboratories, Mumbai, India) and the plates were incubated anaerobically at $37^{\circ} \mathrm{C}$ for $24 \mathrm{hrs}$. After incubation suspected colonies were sub-cultured on the SPS agar plates until they were free from contaminating bacteria. The typical black and cream colonies, suggestive of $C$. perfringens were further streaked on the 5\% sheep blood agar plates and egg yolk agar plates and incubated anaerobically for $24 \mathrm{hr}$. The colonies producing characteristic double zone of haemolysis around them on blood agar and producing zone of opalescence around the colonies on egg yolk agar were suggestive of $C$. perfringens. The isolates were also examined microscopically after staining with Gram's stain. The pure cultures of $C$. perfringens were kept as glycerol stock at $84^{\circ} \mathrm{C}$ and lyophilized using $0.5 \mathrm{M}$ sucrose solution for future use.

\section{Extraction of DNA}

Suspected isolated colonies of $C$. perfringens from agar plates were suspended in $1.5 \mathrm{ml}$ microcentrifuge tubes containing $100 \mu \mathrm{l}$ of distilled water by gentle vortexing. The samples were boiled for $10 \mathrm{~min}$, cooled on ice for $10 \mathrm{~min}$ and centrifuged at $14,000 \times \mathrm{g}$ in a table-top refrigerated microcentrifuge (Cooling Centrifuge, Eppendorf 5418R, Hamburg, Germany) for $10 \mathrm{~min}$. Three microlitres $(\mu \mathrm{l})$ of the supernatant was used as the template for PCR.

\section{Amplification of $16 \mathrm{~S}$ rRNA gene of Clostridium perfringens by polymerase chain reaction}

Isolates of $C$. perfringens were confirmed by amplifying $16 \mathrm{~S}$ rRNA gene of the $C$. perfringens as per Tonooka et al., (2005). The primers used in the experiment have the following sequences: forwardTAACCTGCCTCATAGAGT and reverseTTTCACATCCCACTTAATC. The PCR conditions consisted of initial denaturation at $95^{\circ} \mathrm{C}$ for $5 \mathrm{~min}$, followed by 35 cycles of denaturation at $94^{\circ} \mathrm{C}$ for $30 \mathrm{sec}$, annealing at $49^{\circ} \mathrm{C}$ for $90 \mathrm{sec}$ and extension at $72^{\circ} \mathrm{C}$ for 90 sec. This was followed by final extension at $72^{\circ} \mathrm{C}$ for $10 \mathrm{~min}$. A confirmed isolate of $C$. perfringens type A maintained in the Division was used as positive control while distilled water served as negative control.

\section{Multiplex Polymerase chain reaction}

All the $C$. perfringens isolates were screened for six different toxin genes using a multiplex PCR. These six toxin genes include $\alpha-(c p a)$, $\beta-(c p b), \quad \varepsilon-(e t x), \quad \mathfrak{i}-(c p i), \quad \beta 2-(c p b-2) \quad$ and enterotoxin (cpe). The primers used for the amplification of the genes are shown in Table 1. All the primers were procured from GCC Biotech, Kolkata, India.

All the PCR assays in this study were performed in $25 \mu$ l reaction volume in a thermal cycler (Mastercycler Gradient, Eppendorf AG, Hamburg, Germany). The PCR conditions consisted of initial 
denaturation at $95^{\circ} \mathrm{C}$ for $15 \mathrm{~min}$, followed by 35 cycles of denaturation at $94^{\circ} \mathrm{C}$ for $30 \mathrm{sec}$, annealing at $53^{\circ} \mathrm{C}$ for $90 \mathrm{sec}$ and extension at $72^{\circ} \mathrm{C}$ for $90 \mathrm{sec}$. This was followed by final extension at $72^{\circ} \mathrm{C}$ for $10 \mathrm{~min}$ (Van Asten et al., 2008). Confirmed isolates of $C$. perfringens type $\mathrm{A}$ and $\mathrm{D}$ available in the Division and distilled water were used as positive and negative control, respectively.

Samples $(6 \mu \mathrm{l})$ of PCR products were mixed with $6 \times$ loading buffer and loaded in separate wells on the submerged Agarose gel (1.5\% $\mathrm{w} / \mathrm{v})$. Standard molecular weight marker (Fermentas Life Sciences) was also loaded in one well. The voltage $1-5 \mathrm{~V} / \mathrm{cm}$ was applied across the gel until the bromophenol blue migrated to appropriate distance. The gel was removed and visualized under ultraviolet illumination and photographed with Gel Documentation System (Ultra Cam Digital Imaging, Ultra. Lum. Inc., Claremont, CA).

\section{Results and Discussion}

\section{Isolation and identification of $C$. perfringenes}

In the present study, sheep and goat populations from different regions of Kashmir valley were screened for the presence of $C$. perfringens toxinotypes. After enrichment in cooked meat medium, $C$. perfringens isolates produced typical black centered or creamish colour colonies on SPS agar (Figure 1).

The isolates also produced characteristics double zone of haemolysis and opalescence on sheep blood agar (Figure 2) and egg yolk agar (Figure 3), respectively.

Out of 462 faecal samples of sheep and goats, C. perfringens was isolated from 286 samples (Table 2). All the isolates, which were tentatively identified as $C$. perfringens, amplified $481 \mathrm{bp}$ product corresponding to $16 \mathrm{~S}$
rRNA gene of $C$. perfringens (Figure 4). Out of the 138 adult sheep and 46 lamb samples without diarrhoea, $C$. perfringens was obtained from $63(45.6 \%)$ and $27(58.6 \%)$ samples, respectively. Similarly, 51(71.8\%) and 91(76\%) samples from 71 adult sheep and 121 lambs with diarrhoea, respectively yielded $C$. perfringens.

Likewise, $8(53.3 \%)$ and $16(66.6 \%)$ isolates were recovered from 15 and 24 healthy adult goat and kid samples, respectively. The diarrhoeic samples yielded 17(58.6\%) and $13(72.2 \%)$ isolates from adult goats and kids, respectively.

\section{Multiplex polymerase chain reaction assay:}

Toxinotyping of these isolates was done by multiples PCR (Figure 5). Among the 286 isolates from 462 samples, 228 (79.72\%) were typed as toxinotype A, $197(86.4 \%)$ of which had only cpa gene and 31 (13.6\%) carried both cpa and cpe gene. Out of $228 \mathrm{C}$. perfringens toxinotype $\mathrm{A}, 61(26.7 \%)$ and 18 (7.8) isolates were obtained from healthy adult sheep and lambs respectively. Similarly, $46(20.1 \%)$ and $58(25.4 \%)$ isolates from adult sheep and lambs with diarrhoea, were typed as toxinotype A, respectively. Likewise, of the $228 C$. perfringens toxinotype A isolates, $8(3.5 \%)$ and $12(5.2 \%)$ were recovered from healthy adult goats and kids, respectively. The diarrhoeic samples yielded 15(6.5\%) and $10(4.3 \%)$ type $\mathrm{A}$ isolates from adult goats and kids, respectively.

Other $58(20.2 \%)$ isolates harboured both cpa and etx genes and thus were designated as toxinotype D. Majority of the type D isolates $(58.6 \%)$ were from diarrhoeic lambs and this is followed by healthy lamb (15.5\%), diarrhoeic adult sheep (8.6\%) and others (3.5$5.2 \%$ ). Out of $58 C$. perfringens toxinotype D, $2(3.4 \%)$ and $9(15.5 \%)$ isolates were obtained from healthy adult sheep and lambs 
respectively. Similarly, 5(8.6\%) and $34(58.6 \%)$ isolates from adult sheep and lambs with diarrhoea, were typed as toxinotype $\mathrm{D}$, respectively. Likewise, of the 58 C. perfringens toxinotype $\mathrm{D}$ isolates, $3(5.1 \%)$ were recovered from healthy kids and no type $\mathrm{D}$ toxinotype was found in healthy adult goat. The diarrhoeic samples yielded $2(3.4 \%)$ and $3(5.1 \%)$ type D isolates from adult goats and kids, respectively.

None of the isolates carried $c p b$ or $c p i$ genes indicating the absence of $C$. perfringens toxinotype $\mathrm{B}, \mathrm{C}$ or $\mathrm{E}$ in sheep and goat samples. It was observed that most of the isolates belonged to the toxinotype A, followed by type D. Among the Sheep and goats, most of toxinotype $\mathrm{A}$ isolates were found in adults followed by the young stock. It was also observed that the toxinotype D was mostly detected in diarrhoeic animals especially lambs

Table.1 List of primers used in PCR for amplification of Clostridium perfringens toxin genes

\begin{tabular}{|c|c|c|c|c|c|}
\hline $\begin{array}{l}\text { S. } \\
\text { No. }\end{array}$ & $\begin{array}{l}\text { Target } \\
\text { gene }\end{array}$ & Primer Sequence $\left(5^{\prime}-3^{\prime}\right)$ & $\begin{array}{l}\text { Primer } \\
\text { conc. } \\
(\mu \mathrm{M})\end{array}$ & $\begin{array}{l}\text { Produc } \\
\text { t size } \\
(\text { bp) }\end{array}$ & Reference \\
\hline 1. & cpa & $\begin{array}{l}\text { F-GCTAATGTTACTGCCGTTGA } \\
\text { R-CCTCTGATACATCGTGTAAG }\end{array}$ & 0.4 & 324 & \multirow{6}{*}{$\begin{array}{lr}\text { Van } & \text { Asten } \\
\text { et al., } & (2008)\end{array}$} \\
\hline 2. & $c p b$ & $\begin{array}{l}\text { F-GCGAATATGCTGAATCATCA } \\
\text { R-GCAGGAACATTAGTATATCTTC }\end{array}$ & 0.4 & 195 & \\
\hline 3. & $e t x$ & $\begin{array}{l}\text { F-TGGGAACTTCGATACAAGCA } \\
\text { R-AACTGCACTATAATTTCCTTTTCC }\end{array}$ & 0.4 & 376 & \\
\hline 4. & $c p i$ & $\begin{array}{l}\text { F-AATGGTCCTTTAAATAATCC } \\
\text { R-TTAGCAAATGCACTCATATT }\end{array}$ & 0.4 & 272 & \\
\hline 5. & $c p b 2$ & $\begin{array}{l}\text { F-AAATATGATCCTAACCAACAA } \\
\text { R-CCAAATACTCTAATYGATGC }\end{array}$ & 0.4 & 548 & \\
\hline 6. & cpe & $\begin{array}{l}\text { F-TTCAGTTGGATTTACTTCTG } \\
\text { R-TGTCCAGTAGCTGTAATTGT }\end{array}$ & 0.4 & 485 & \\
\hline
\end{tabular}

Table.2 Details of the isolates of $C$. perfringens from sheep and goats

\begin{tabular}{|c|c|c|c|c|c|c|}
\hline Species & Age group & $\begin{array}{c}\text { Nature of } \\
\text { samples }\end{array}$ & $\begin{array}{c}\text { No. of } \\
\text { samples }\end{array}$ & $\begin{array}{c}\text { Total isolates } \\
(\%)\end{array}$ & $\begin{array}{c}\text { Type A } \\
(\%)\end{array}$ & $\begin{array}{r}\text { Type D } \\
(\%)\end{array}$ \\
\hline \multirow{4}{*}{ Sheep } & \multirow{2}{*}{ Adult } & Healthy & 138 & $63(22.02)$ & $61(26.7)$ & $2(3.4)$ \\
\hline & & Diarrhoeic & 71 & $51(17.8)$ & $46(20.1)$ & $5(8.6)$ \\
\hline & \multirow{2}{*}{ Lamb } & Healthy & 46 & $27(9.4)$ & $18(7.8)$ & $9(15.5)$ \\
\hline & & Diarrhoeic & 121 & $91(31.8)$ & $58(25.4)$ & $34(58.6)$ \\
\hline \multirow{4}{*}{ Goat } & \multirow{2}{*}{ Adult } & Healthy & 15 & $8(2.7)$ & $8(3.5)$ & 0 \\
\hline & & Diarrhoeic & 29 & $17(5.9)$ & $15(6.5)$ & $2(3.4)$ \\
\hline & \multirow{2}{*}{$\mathrm{Kid}$} & Healthy & 24 & $16(5.5)$ & $12(5.2)$ & $3(5.1)$ \\
\hline & & Diarrhoeic & 18 & $13(4.5)$ & $10(4.3)$ & $3(5.1)$ \\
\hline \multicolumn{3}{|c|}{ Total } & 462 & $286(61.9)$ & $228(79.72)$ & $58(20.2)$ \\
\hline
\end{tabular}


Fig.1 Cream colored colonies of Clostridium perfringens on SPS agar

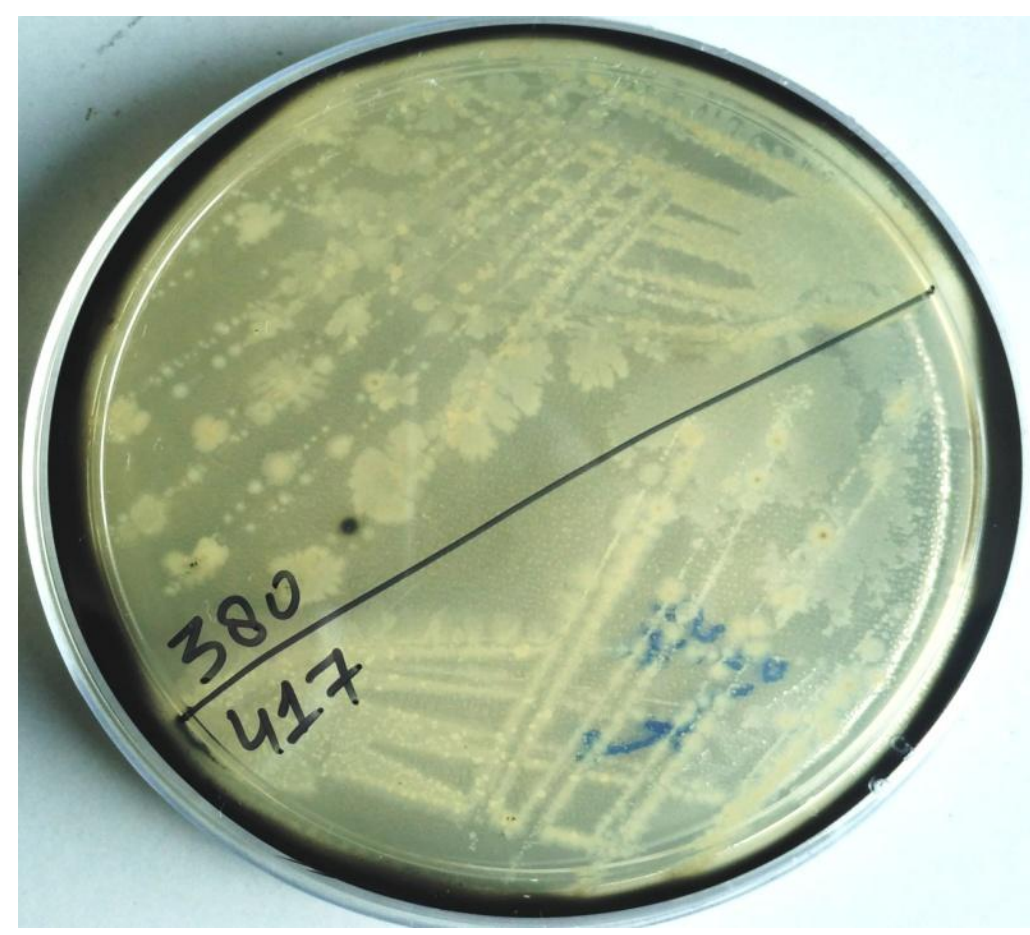

Fig.2 Double zone of hemolysis produced by Clostridium perfringens on sheep blood agar

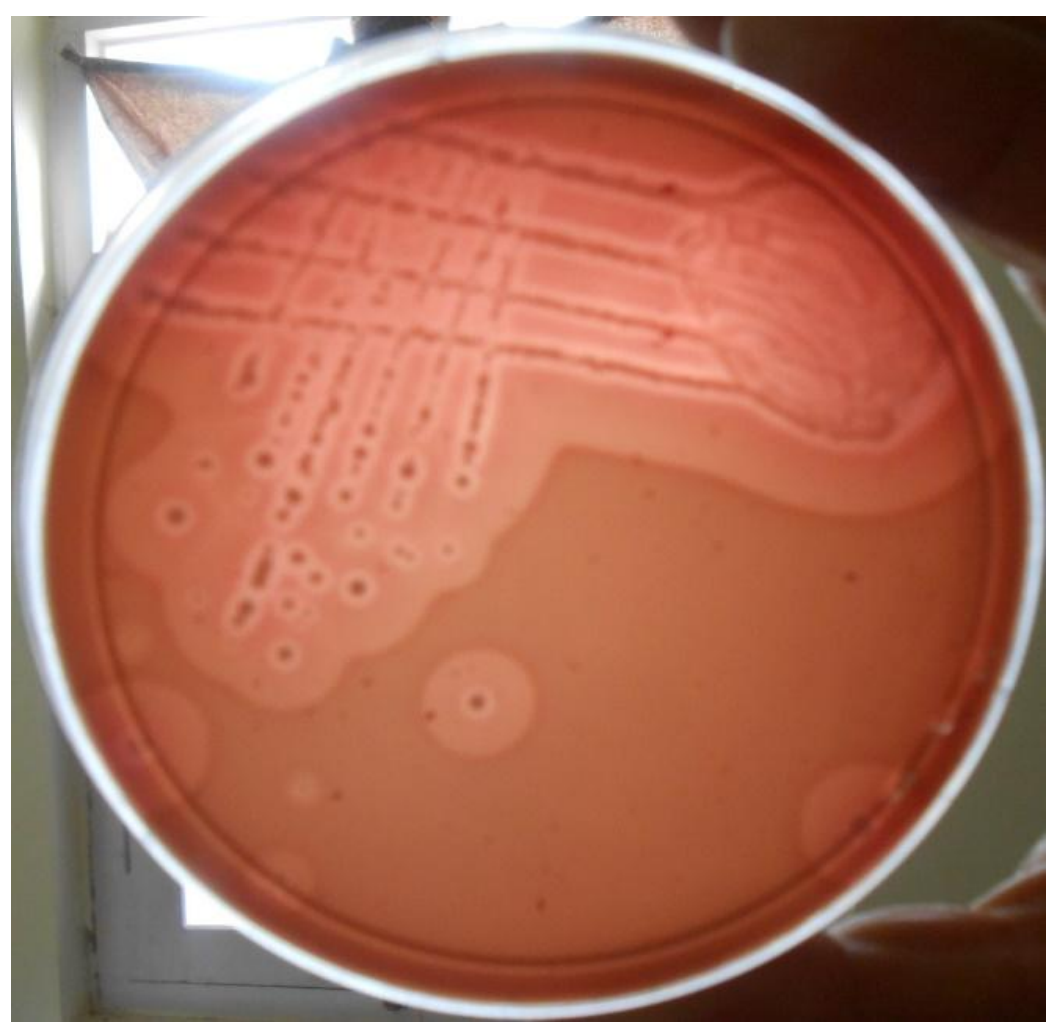


Fig.3 Lecithinase activity of Clostridium perfringens on egg yolk agar after 24 hrs of growth

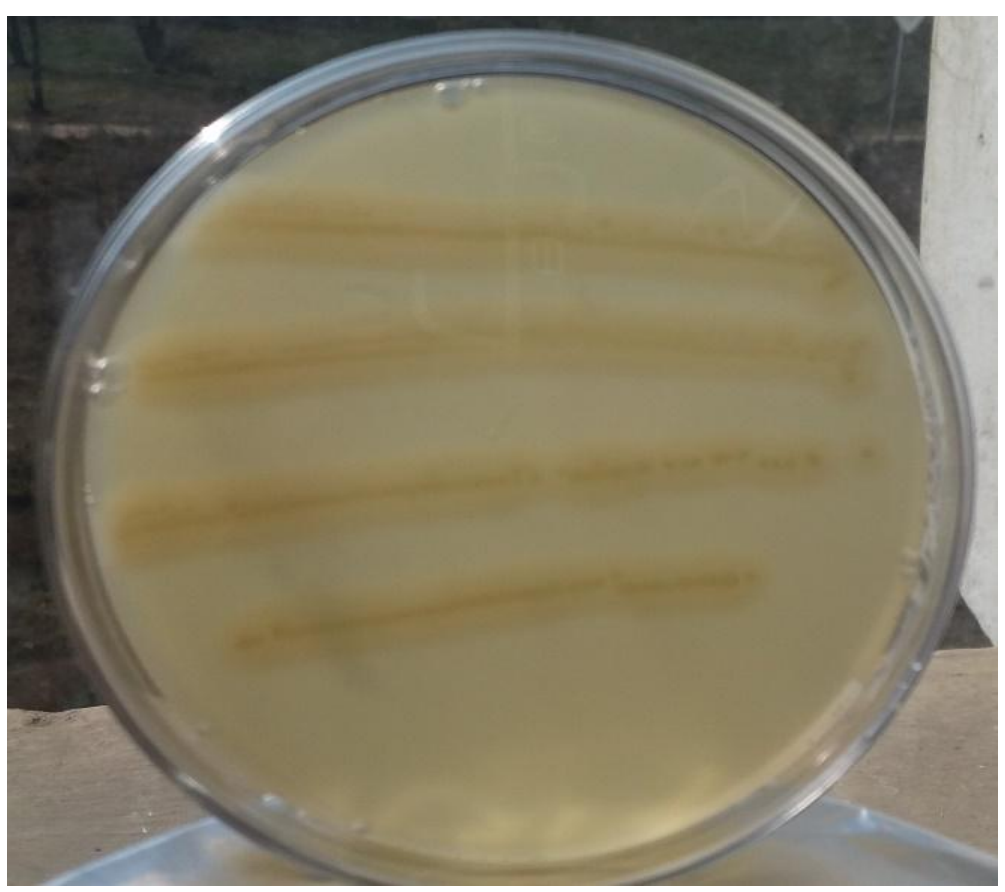

Fig.4 Agarose gel electrophoresis showing 481bp amplicon of hsp65 rRNA gene of Clostridium perfringens

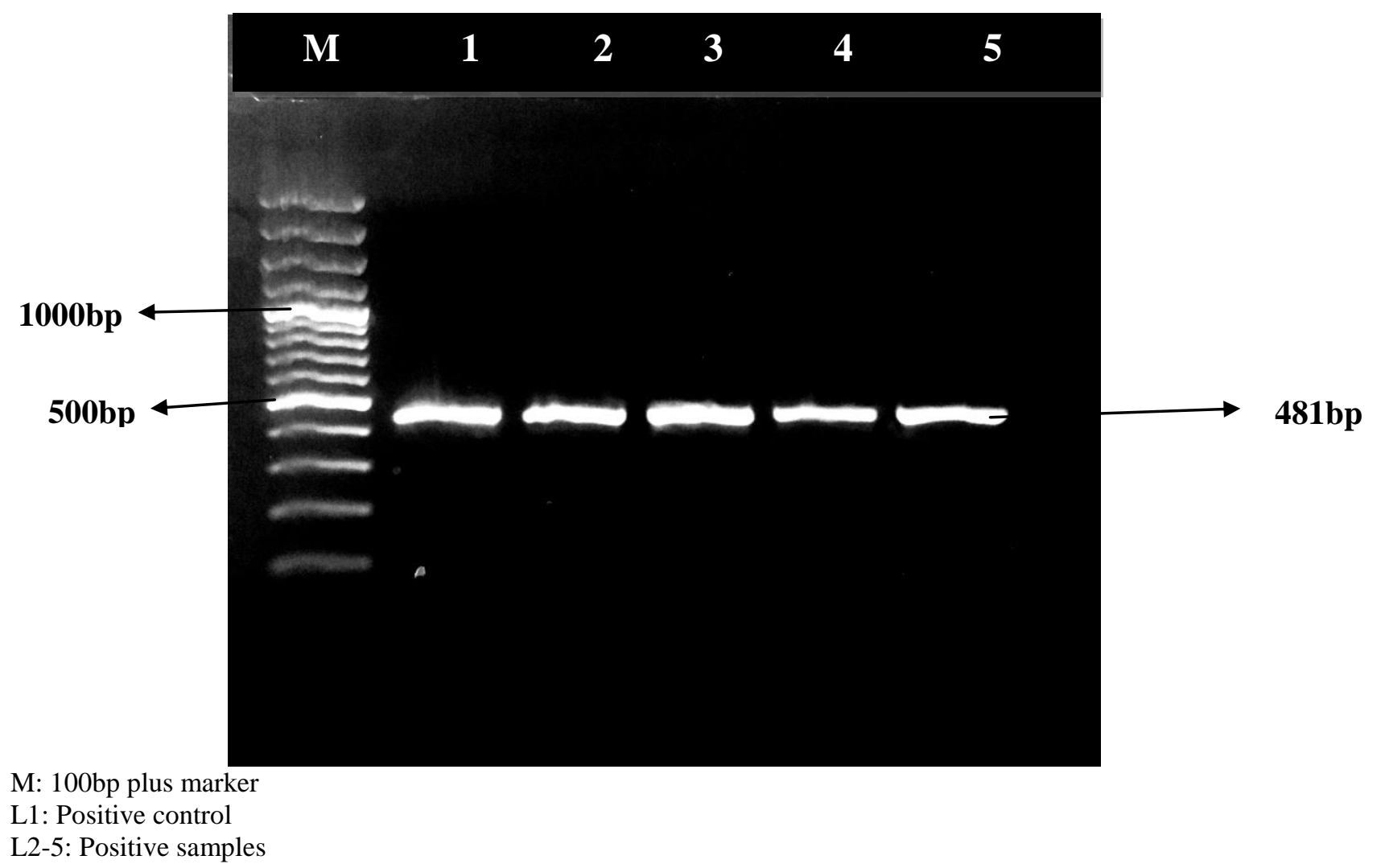


Fig.5 Agarose gel electrophoresis of multiplex PCR amplicons of different virulence genes of Clostridium perfringens

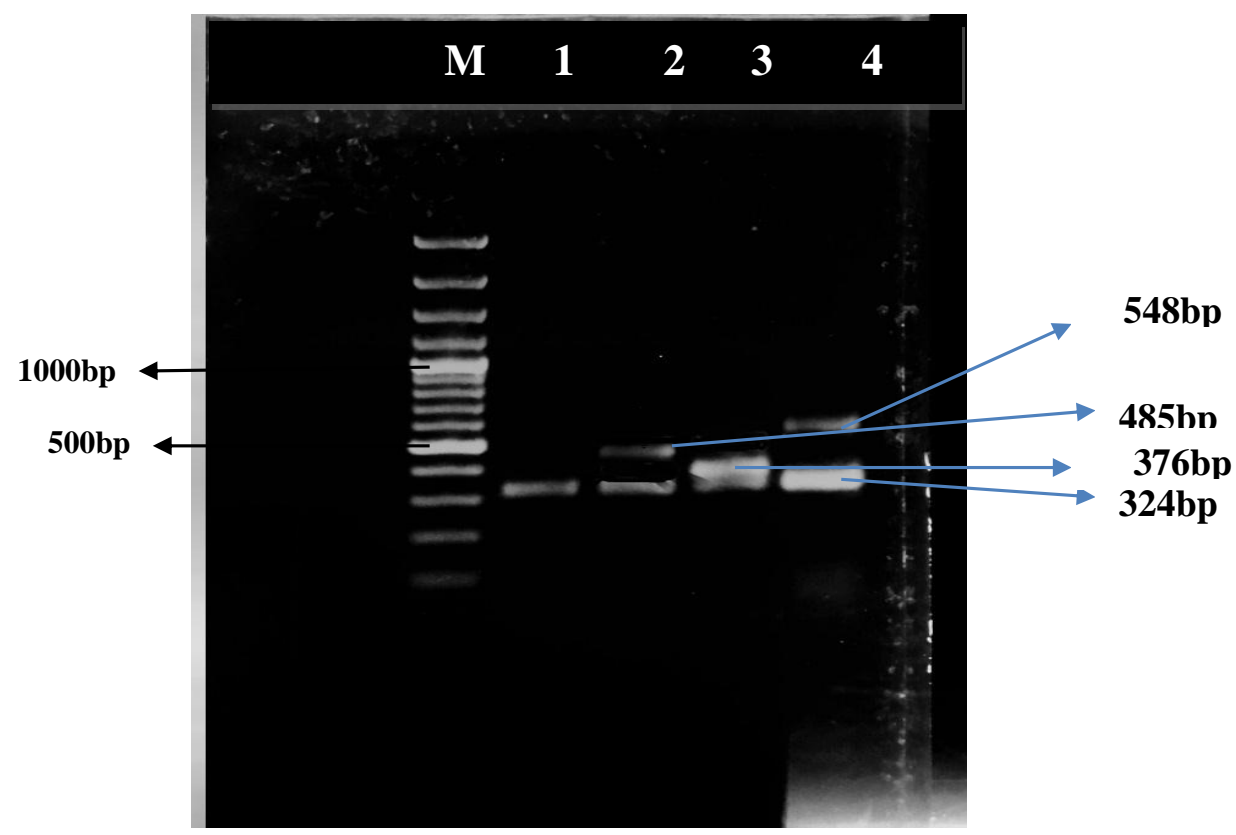

M: 100bp plus marker

L1: C. perfringens Type A with amplified cpa only

L2: $C$. perfringens Type A with amplified cpa and cpe genes

L3: $C$. perfringens Type D with amplified cpa and etx genes

L4: C. perfringens Type A with amplified cpa and beta-2 genes

Clostridium perfringens causes a wide range of enteric and other infections including fatal intoxications in different animal species (Songer, 1996, Songer, 1997; Markey et al., 2013). These isolates may be found in the intestine of normal animals, including sheep, goats, and cattle (Uzal and Songer, 2008). Strains of $C$. perfringens have been classified into five toxigenic types (A through $\mathrm{E}$ ) based on the production of the four commonly named major toxins- $\alpha, \beta, \varepsilon$ and 1 (Hatheway, 1990; Badagliacca et al., 2010).). Among the toxinotypes, type $\mathrm{D}$, which are positive for $\varepsilon$ (ETX), are responsible for fatal enterotoxaemia or pulpy kidney disease in sheep and other small ruminants (Souza et al., 2010).

In the present study, we investigated the occurrence of $C$. perfringens, the causative agent of enteritis in sheep and goats of
Kashmir valley as well as characterized their toxinotype. RCM medium was used for enrichment of samples. For further isolation, SPS agar was used and it supported appreciable luxuriant growth with creamish or black centered colonies after $24 \mathrm{hrs}$ of incubation anaerobically. In a study, Shanmugasamy and Rajeswar (2012) reported that the frequency of isolation of $C$. perfringens was more with Robertson Cooked Meat Medium along with BHI broth than thioglycollate broth alone.The isolates produced double zone of haemolysis on sheep blood and lecithinase activity on egg yolk agar, the characteristics features of $C$. perfringens described by Quinn et al., (2002).

In the present study, $C$. perfringens was isolated from $61.9 \%$ of total samples from sheep and goats. From healthy adults (without diarrhoea), the isolation rate was found to be 
$46.4 \%$, while the rate was $61.4 \%$ from healthy lambs and kids. In case of diarrhoeic animals, isolation rate was found to be $68 \%$ in case of adults, while it was $74.8 \%$ in young stock.

No reports are available from Kashmir valley to compare the results. However, Phukan et al., (1997) isolated $C$. perfringens from the diarrhoeic goats in Assam. Das et al., (2012) also isolated $C$. perfringens from faecal samples of cattle with diarrhoea in Meghalaya. Recently, Kumar et al., (2014) reported prevalence of $C$. perfringens toxin genotypes in enterotoxaemia suspected sheep flocks from Andhra Pradesh. C. perfringens was isolated from $69.29 \%$ enterotoxaemia suspected flocks and $39.71 \%$ from healthy flocks.

Typing of $C$. perfringens by multiplex PCR revealed that the isolates belonged to the toxinotypes A and D. Compared to conventional techniques, the PCR method has been shown to be much more rapid, giving results in a few hours and it is much more reliable for toxinotyping. In the present study, out of 114 isolates from healthy animals 100 $(87.7 \%)$ isolates were found to be $C$. perfringens type A, while 14 (12.3\%) were type D. Similarly, $129(75 \%)$ and $43(25 \%)$ out of $172 C$. perfringens isolates from diarrhoeic animals were type $\mathrm{A}$ and type $\mathrm{D}$, respectively. These findings were similar to Kumar et al., (2014) who reported genotyping of the 97 isolates of $C$. perfringens by a multiplex PCR from enterotoxaemia suspected flocks of sheep and observed $67.01 \%, 11.34 \%$ and $21.65 \%$ isolates as type $\mathrm{A}, \mathrm{C}$ and $\mathrm{D}$, respectively. They also recorded $92.59 \%$ and $7.40 \%$ type $A$ and D, respectively, from healthy flocks. Kalender et al., (2005) also reported that $52 C$. perfringens isolates from diseased sheep, $64 \%$ were type A, $21 \%$ were type D and $15 \%$ were type $\mathrm{C}$, while types $\mathrm{B}$ and $\mathrm{E}$ were not identified. The type $\mathrm{D}$ isolates were significantly higher from the lambs with and without diarrhea and the reason for higher prevalence in healthy lambs may be due to close contact with diarrhoeic animals. Kumar et al., (2016), recently reported that out of 42 isolates from enterotoxaemia suspected lambs, $30(53.6 \%)$ were type A, $9(16.0 \%)$ type D and $5(8.9 \%)$ were type C.

In conclusion, the rate of isolation of $\mathrm{C}$. perfringens was more from diarrhoeic animals than the healthy ones and C. perfringens type A predominates in both healthy and diarrhoeic sheep and goats, irrespective of their age. However, type D isolates were significantly more from healthy and diarrhoeic lambs than other animals.

\section{Acknowledgement}

The authors thankfully acknowledges the Indian Council of Agricultural Research, New Delhi for the facilities under the Niche Area of Excellence on Anaerobic Bacteria project entitled "Study of Clostridium perfringens and Dichelobacter nodosus (Anaerobic Bacteriology)" utilized for this study.

\section{References}

Ahsani, M.R., Mohammadabadi, M.R. and Shamsaddini, M.B. 2010. Clostridium perfringens isolate typing by multiplex PCR. Journal of Venomous Animals and Toxins including Tropical Diseases 16: 573-578..

Badagliacca, P., Di Providdo, A., Scattolini, S., Pompei, G. and Di Giannatale, E. 2010. Toxin genotyping of Clostridium perfringens strains using a polymerase chain reaction protocol. Veterinaria Italiana 46:113-118.

Chen, J., Rood, J.I. and McClane, B.A. 2011. Epsilon-toxin production by Clostridium perfringens type D strain CN3718 is dependent upon the 
Agroperon but not the VirS/VirR twocomponent regulatory system. Molecular Biology 2: 1-11.

Das, A., Mazumder, Y., Dutta, B.K., Shome, B.R., Bujarbaruah, K.M. and Kumar, R. 2012. Molecular typing of Clostridium perfringens isolated from diarrhoeic cattle. Journal of Animal Science Advances 2: 226-229.

Elsify, A., Tarabess, R., Nayel, M.A., Salama, A., Allaam, M., Abdel-gaber, M., Hassan, H., Zaghawa, A. and Elballal, S. 2016. Bacteriological and molecular studies on Clostridium perfringens isolated from sheep in three Egyptian provinces. African Journal of Microbiology Research 10: 725-732.

Hatheway, C.L. 1990. Toxigenic clostridia. Clinical Microbiology Review 3: 66-98.

Kadra, B., Guillou, J.P., Popoff, M. and Bourlioux, P. 1999. Typing of sheep clinical isolates and identification of enterotoxigenic Clostridium perfringens strains by classical methods and by polymerase chain reaction (PCR). FEMS Immunology and Medical Microbiology24: 259-266.

Kalender, H., Ertas, H.B., Cetinkaya, B., Muz, A., Arslan, N. and Kilic, A. 2005. Typing of isolates of Clostridium perfringens from healthy and diseased sheep by multiplex PCR. Veterinary Medicine Czech 50: 439-442.

Kumar, N.V., Sreenivasulu, D. and Reddy, Y.N. 2014. Prevalence of Clostridium perfringens toxin genotypes in enterotoxemia suspected sheep flocks of Andhra Pradesh. Veterinary World 7: 1132-1136.

Kumar, N.V., Sreenivasulu, D. and Reddy, Y.N. 2016. Identification of Clostridium perfringens type $\mathrm{C}$ and $\mathrm{D}$ from enterotoxemia suspected lambs in Andhra Pradesh. Indian Veterinary Journal 93: 29-31.
Li, J., Adams, V., Bannam, T.L., Miyamoto, K., Garcia, J.P., Francisco A. Uzal, F.A., Rood, J.I. and McClanea, B.A. 2013. Toxin plasmids of Clostridium perfringens. Microbiology and Molecular Biology Reviews 77: 208233.

Markey, B., Leonard, F., Archambault, M., Cullinane, A. and Maguire, D. 2013. Clinical Veterinary Microbiology, $2^{\text {nd }}$ Edition, Mosby, Elsevier, pp 229.

Phukan, A., Dutta, G.N., Daube, G. and Das, B.C. 1997. Isolation, identification and serotyping of Clostridium perfringens from goats. Indian Journal of Animal Sciences 67: 204.

Quinn, P.J., Markey, B.K., Carter, M.E., Leonard, W.J.F.C. and Meguire, D. 2002. Veterinary Microbiology and Microbial Disease, 2nd edition, Blackwell Science, pp: 84-96.

Rood, J.L. 1998.Virulence genes of Clostridum perfringens. Annual Review of Microbiology 52:333-360.

Shanmugasamy, M. and Rajeswar, J. 2012. Alpha toxin specific PCR for detection of toxigenic strains of Clostridium perfringens in Poultry. Veterinary World 5: 365-368.

Smedley, J.G., Fisher, D.J., Sayeed, S., Chakrabarti, G. and McClane, B.A. 2004. The enteric toxins of Clostridium perfringens. Reviews of Physiology Biochemistry and Pharmacology152: 183-204.

Songer, J.G. 1996. Clostridial enteric diseases of domestic animals. Clinical Microbiology Review 9: 216-234.

Songer, J.G. 1997. Clostridial diseases of animals. Academic Press, London, UK.

Souza, A.M., Reis, J.K.P., Assis, R.A., Horta, C.C., Siqueira, F.F., Facchin, S., Alvarenga, E.R., Lobato, F.C.F and Kalapothakis, E. 2010. Molecular cloning and expression of epsilon toxin 
of Clostridium perfringens type D and tests of animal immunization. Genetics and Molecular Research 9: 266-276.

Tonooka, T., Sakata, S., Kitahara, M., Hanai, M., Ishizeki, S., Takada, M., Sakamoto, M. and Benno, Y. 2005. Detection and quantification of four species of the genus Clostridium in infant feces. Microbiology and Immunology 49: 987-992.

Uzal, F.A. and Songer, J.G. 2008. Diagnosis of Clostridium perfringens intestinal infections in sheep and goats. Journal of
Veterinary Diagnostic Investigation 20:253-265.

Van Asten, A.J.A.M., Wiel, C.W., Van Nikolaou, G., Houvers, D.J. and Grone, A. 2009. A multiplex PCR for toxin typing of Clostridium perfringens. Veterinary Microbiology 136: 411-412. Varga, J.J., Nguyen, V., O'Brien, D.K., Rodgers, K., Walker, R.A. and Melville, S.B. 2006. Type IV pili-dependent gliding motility in the Gram-positive pathogen Clostridium perfringens and other Clostridia. Molecular Microbiology 62: 680-694.

\section{How to cite this article:}

Rasool, S., I. Hussain, S.A. Wani, Z.A. Kashoo, Q. Beigh, Q. Nyrah, N. Nazir, T. Hussain, A.H. Wani and Qureshi, S. 2017. Molecular Typing of Clostridium perfringens Isolates from Faecal Samples of Healthy and Diarrhoeic Sheep and Goats in Kashmir, India. Int.J.Curr.Microbiol.App.Sci. 6(10): 3174-3184. doi: https://doi.org/10.20546/ijcmas.2017.610.372 